\title{
Polymerase chain reaction with sequence-specific primers-based genotyping of the human Dombrock blood group DO1 and DO2 alleles and the DO gene frequencies in Chinese blood donors
}

\author{
G.-G. Wu' ' S.-Z. Jin ' , Z.-H. Deng ${ }^{1}$ \&t T.-M. Zhao ${ }^{2}$ \\ ${ }^{1}$ Shenzhen Institute of Transfusion Medicine, Shenzhen, China, \\ ${ }^{2}$ National Institutes of Health, Bethesda, MD, USA
}

The Dombrock blood group system (ISBT 014, D0) was discovered 36 years ago and has been associated with haemolytic transfusion reactions [1,2]. Two common antigens, D01 $\left(\mathrm{Do}^{\mathrm{a}}\right)$ and D02 $\left(\mathrm{Do}^{\mathrm{b}}\right)$, and other three high-incidence antigens - D03 (Gy $)$, D04 (Hy) and D05 (Jo $)$ - were identified using serological methods [1,3-5]. Usually it is difficult to obtain monospecific D0-typing reagents and there are only limited DO gene-frequency studies, especially in the Chinese population [2,6]. As serological D0 typing has severe limitations, establishing a DNA-based $D O$ genotyping technique appears to be essential. Recently in a linkage study the $D O$ locus was assigned to chromosome 12p12.3-p13.2 (chromosome 12, short arm, region 1, band 2, sub-band 3, through band 3, sub-band 2) [7]. More recently, the $D O$ gene has been successfully cloned, ending a long period of searching for the molecular basis of the DO1/DO2 polymorphism [8]. Homology studies suggested that the DO molecule is a member of the adenosine $5^{\prime}$-diphosphate (ADP)-ribosyltransferase ectoenzyme gene family [8]. $\mathrm{DO} 1$ and $\mathrm{DO} 2$ alleles are the result of a single nucleotide substitution causing an amino acid change within an encoded arginine-glycine-aspartic acid (RGD) motif of the molecule [8]. On the basis of these findings, we have developed, for the first time, a polymerase chain reaction with sequence-specific primers (PCR-SSP)-based DO1 and DO2 genotyping method using newly designed allele-specific primers.

The $D O$ gene comprises 3 exons spanning 13743 base pairs (bp) and predicts a peptide of 314 amino acid residues. A single nucleotide change from $\mathrm{A}$ to $\mathrm{G}$ at nucleotide position 892 (numbering according to the DOK1 clone, GenBank acc. no.: AF29004) within exon 2 results in the substitution of asparagine (N) for aspartic acid (D) at position 265 of the protein sequence. Serological testing indicated that N265 and D265 corresponded to the phenotypes D0:1,-2 [DO $(\mathrm{a}+\mathrm{b}-\mathrm{-})]$ and D0:-1,2 [DO(a-b+)], respectively [8]. In order to detect A892G substitution, two allele-specific reverse primers and a single forward-consensus primer were designed according to the DOK1 clone sequence and the human chromosome 12 working draft sequence (BAC clone, GenBank acc. no.: AC007655). The primer sequences, primer mixes and corresponding PCR products are shown in Table 1. Primer pairs DOF/D01R and DOF/DO2R were used to identify DO1 and DO2 alleles, respectively. Primers HGHF and HGHR were included in all PCR reactions to amplify the internal positivecontrol PCR product, a 427-bp fragment from the human growth hormone (HGH) gene.

Table 1 Primers for $D O$ typing and amplification of $D O$ exon 2

\begin{tabular}{|c|c|c|c|c|c|}
\hline Detection of: & Primer $^{\mathrm{a}}$ & Nucleotide sequence $\left(5^{\prime}-3^{\prime}\right)$ & Position $^{b}$ & Primer mix & PCR product size (bp) \\
\hline D01 & D01R & TGACCTCAACTGCAACCAGTT & 51210 to 51230 & D0F/D01R & 162 \\
\hline \multirow[t]{2}{*}{ DO2 } & $\mathrm{D} 02 \mathrm{R}$ & GACCTCAACTGCAACCAGTC & 51211 to 51230 & DOF/D02R & 161 \\
\hline & DOF & CAGGAGTTTGGGAACCAGAC & 51371 to 51352 & & \\
\hline \multirow[t]{2}{*}{ DO exon 2} & $51979 \mathrm{~F}$ & GTTTCCAGGAGAAGACTTACCC & 51979 to 51958 & $51979 F$ & 858 \\
\hline & $51122 R$ & GAGCAGTGGTCTGTGATCCTG & 51122 to 51142 & $51122 R$ & \\
\hline \multirow[t]{2}{*}{$H G H$} & HGHF & GCCTTCCСААССАТTCССТTA & 893 to 913 & HGHF & 427 \\
\hline & HGHR & TCACGGATTTCTGTTGTGTTTC & 1319 to 1298 & $\mathrm{HGHR}$ & \\
\hline
\end{tabular}

${ }^{\mathrm{a}} \mathrm{F}$ and $\mathrm{R}$ indicate forward and reverse primers, respectively.

${ }^{b}$ Numbering of $D O$ was according to a sequenced BAC clone (GenBank acc. no.: AC007655); HGH numbering was according to clone HGH-N (GenBank acc. no.: M13438). 
Table 2 DO gene frequencies in Chinese blood donors

\begin{tabular}{lccll}
\hline Genotype & $\begin{array}{l}\text { Number } \\
\text { observed }\end{array}$ & $\begin{array}{l}\text { Number } \\
\text { expected }\end{array}$ & \multicolumn{1}{l}{$\boldsymbol{\chi}^{2}$} & $\begin{array}{l}\text { Gene } \\
\text { frequency }\end{array}$ \\
\hline DO $1 / 1$ & 3 & $3 \cdot 08$ & $0 \cdot 0021$ & \\
DO $1 / 2$ & 54 & $53 \cdot 82$ & $0 \cdot 0006$ & $D 01=0 \cdot 1027$ \\
DO $2 / 2$ & 235 & $235 \cdot 10$ & $0 \cdot 0000$ & DO2 $=0.8973$ \\
& 292 & $292 \cdot 00$ & $\Sigma \chi^{2}=0 \cdot 0027$ & \\
& & & $P_{(1)}>0 \cdot 95$ & \\
\hline
\end{tabular}

The initial PCR was carried out with $1 \mu$ of DNA sample (0.15-0.5 $\mu \mathrm{g}), 1 \mu \mathrm{l}$ of diluted Taq polymerase (0.25-0.33 U) and $8 \mu \mathrm{l}$ of DO typing PCR mix in a final $10-\mu$ reaction volume. After denaturation for $5 \mathrm{~min}$ at $95^{\circ} \mathrm{C}$, samples were subjected to 30 cycles of PCR in a DNA thermal cycler. Each cycle comprised $95{ }^{\circ} \mathrm{C}$ for $30 \mathrm{~s}, 60{ }^{\circ} \mathrm{C}$ for $30 \mathrm{~s}$ and $72{ }^{\circ} \mathrm{C}$ for $1.5 \mathrm{~min}$, and was followed by a final extension at $72{ }^{\circ} \mathrm{C}$ for $5 \mathrm{~min}$. PCR products were analysed by electrophoresis on a $2 \%$ agarose gel containing $0.5 \mu \mathrm{g} / \mathrm{ml}$ ethidium bromide and then visualized using UV transillumination. The DO typing PCR mix contained $10 \mathrm{~mm}$ Tris- $\mathrm{HCl}(\mathrm{pH} \mathrm{8.3),} 50 \mathrm{~mm} \mathrm{KCl}$, $1.5 \mathrm{~mm} \mathrm{MgCl}_{2}, 0.001 \%$ (wt/vol) gelatin, $0.2 \mathrm{~mm}$ dNTPs, $0.5 \mu \mathrm{M}$ of each DO forward and reverse primer, and $0 \cdot 2 \mu \mathrm{M}$ of each HGHF and HGHR primer. All PCR mixes were prepared in advance as a 'ready-to-use' kit (G \& T Biotech, Rockville, MD). Eight microlitres of the mix was stored at $-20^{\circ} \mathrm{C}$ under $8 \mu \mathrm{l}$ of mineral oil either in $0 \cdot 2-\mathrm{ml}$ PCR tubes or in 96-well PCR plates.

A total of 292 DNA samples from unrelated healthy Chinese blood donors were typed for $\mathrm{DO} 1$ and $\mathrm{DO} 2 \mathrm{using}$ the assay described above. The genomic DNA was isolated from $0.3 \mathrm{ml}$ of EDTA or ACD anticoagulated blood using a DNA purification kit (G \& T Biotech). The gene frequencies were $0 \cdot 1027$ for $D 01$ and $\mathbf{0 . 8 9 7 3}$ for DO2, showing a good fit to the Hardy-Weinberg equilibrium (Table 2).

Validation criteria are essential to check the reliability and specificity of the typing method. Thirty DNA samples randomly selected from 292 donors were repeatedly tested and a concordance rate of 100\% was observed. In addition, the validity of this method was verified by sequencing analysis. The complete $D O$ exon 2 regions of two $D O$ homozygous samples, DO1/1 and D02/2 (Fig. 1a, donor 1 and donor 2), was first amplified by PCR using flanking primers $51979 \mathrm{~F}$ and 51122R (Table 1) and then sequenced. A total of $782 \mathrm{bp}$ was sequenced around exon 2 of the DO gene (GenBank acc. nos: AF340233 for D01/1 and AF340234 for D02/2). Three single-nucleotide differences between $D 01 / 1$ and DO2/2 individuals were found. Two changes, TAC to TAT encoding a Tyr at codon 126 and CTT to CTC encoding a Leu at codon 208, were silent substitutions. The third substitution, A to G at nucleotide position 892 (Fig. 1b), corresponded to DO1 and

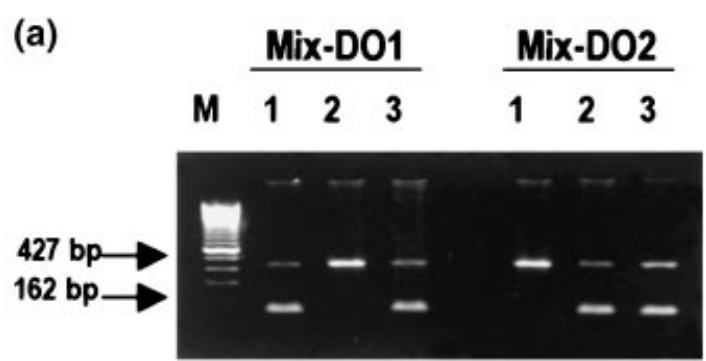

(b)

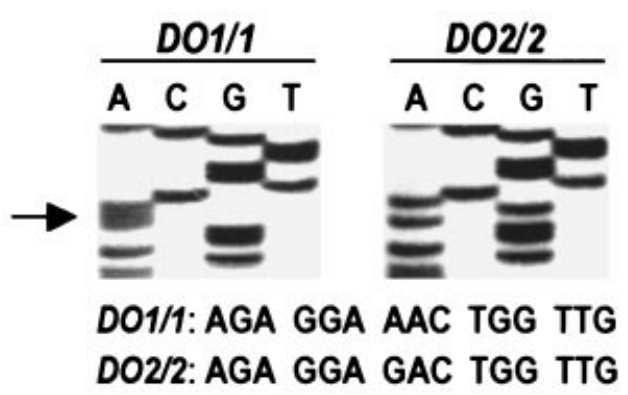

Fig. $1 D 01$ and D02 genotyping by polymerase chain reaction with sequence-specific primers (PCR-SSP) and the sequence of the $D O$ exon 2 at codon 265. (a) Genomic DNAs from three donors, lanes 1-3, were amplified by D01 mix and D02 mix, separately. The PCR products were separated on a $2 \%$ agarose gel containing ethidium bromide. A 427-bp fragment of $\mathrm{HGH}$ was used as an internal control. Lane M shows a 100-bp DNA ladder (Gibco/BRL, Gaithersburg, MD). The genotype can be concluded from the presence of specific PCR products (162 bp for D01, 161 bp for D02). Donor 1, D01/1; Donor 2, D02/2; Donor 3, D01/2. (b) The arrow indicates nucleotide position 892 in codon 265. The homozygous genotype $D O 1 / 1$ has the sequence AAC (Asn 265) at codon 265 of the D0 gene; the homozygous genotype D02/2 has the sequence GAC (Asp 265).

DO2 alleles, as reported previously [8]. Sequence alignment analysis indicated that the DNA sequences of these two Chinese samples are identical to the DOK1 and BAC clone sequences (data not shown), further supporting the validity of this typing method.

In conclusion, here we described a simple, accurate and inexpensive method of $D O$ genotyping, which does not require the additional steps of probe hybridization or restriction enzyme digestion. The typing results can be visualized on a single photograph within $3 \mathrm{~h}$, making this reliable method suitable for large-scale typing of potential blood donors without serological backup.

\section{References}

1 Daniels GL, Anstee DJ, Cartron JP, Dahr W, Issitt PD, Jørgensen J, Kornstad L, Levene C, Lomas-Francis C, Lubenko A, Mallory D, Moulds JJ, Okubo Y, Overbeeke M, Reid ME, Rouger P, Seidl S, Sistonen P, Wendel S, Woodfield G, Zelinski T: Blood Group Terminology 1995: From the ISBT Working Party on Terminology for Red Cell Surface Antigens. Vox Sang 1995; 69:265-279

2 Daniels G: Human Blood Groups. Oxford, Blackwell Science Ltd, 1995 
3 Swanson J, Polesky HF, Tippett P, Sanger R: A 'new' blood group antigen, Do ${ }^{\mathrm{a}}$. Nature 1965; 206:313

4 Molthan L, Crawford MN, Tippett P: Enlargement of the Dombrock blood group system: the finding of anti-Dob. Vox Sang 1973; 24:382-384

5 Banks JA, Hemming N, Poole J: Evidence that the Gy ${ }^{\mathrm{a}}$, Hy and Jo antigens belong to the Dombrock blood group system. Vox Sang 1995; 68:177-182

6 Strupp A, Cash K, Uehlinger J: Difficult in identifying antibodies in the Dombrock blood group system in multiply alloimmunized patients. Transfusion 1998; 38:1022-1035

7 Mauthe J, Coghlan G, Zelinski T: Confirmation of the assignment of the Dombrock blood group locus $(D O)$ to chromosome $12 \mathrm{p}$ : narrowing the boundaries to $12 \mathrm{p} 12.3-\mathrm{p} 13.2$. Vox Sang 2000 ; 79:53-56
8 Gubin AN, Njoroge JM, Wojda U, Pack SD, Rios M, Reid ME, Miller JL: Identification of the Dombrock blood group glycoprotein as a polymorphic member of the ADP-ribosyltransferase gene family. Blood 2000; 96:2621-2627

Tong-Mao Zhao

Molecular and Cellular Immunogenetics Section NIAID

National Institutes of Health

Building 9, Room 1E124

9000 Rockville Pike

Bethesda

MD 20892

USA

E-mail: tzhao@niaid.nih.gov 